\title{
Rivaroxaban in Recurrent Ischemic Stroke Due to Protein S Deficiency: A Case Report
}

\author{
Saba Naghavi $\cdot$ Ahmad Pourmohammadi $\cdot$ Iman Adibi
}

Received: December 13, 2020 / Accepted: January 19, 2021 / Published online: January 30, 2021

(c) The Author(s) 2021

\section{ABSTRACT}

Protein S deficiency is a thrombophilia associated with an increased risk of thromboembolism. Previous studies have shown its role as a predisposing factor for venous thromboembolism, but its role in recurrent arterial ischemic stroke remains uncertain. Here we report a patient with recurrent ischemic stroke due to protein $\mathrm{S}$ deficiency. Oral anticoagulant treatment with vitamin $\mathrm{K}$ antagonist (VKA) drugs is used to treat and prevent thromboembolic events caused by thrombophilia, but it has many limitations, especially in the case of recurrent thromboembolic events. Direct oral anticoagulants (DOACs) have many advantages over VKA. Previous studies have shown that they are safe in cases of thrombophilia, but they are not well studied in recurrent ischemic stroke due to protein $S$ deficiency. In this study our patient was treated with rivaroxaban. Protein $S$ deficiency may be a predisposing factor in recurrent ischemic stroke, and rivaroxaban can be a safe and effective treatment option. Further studies are needed to confirm our findings.

S. Naghavi · A. Pourmohammadi · I. Adibi $(\bowtie)$ Isfahan Neurosciences Research Center, Isfahan University of Medical Sciences, Isfahan, Iran e-mail: I_adibi@med.mui.ac.ir

I. Adibi

Department of Neurology, School of Medicine, Isfahan University of Medical Sciences, Isfahan, Iran
Keywords: Arterial thrombosis; Case report; Protein S deficiency; Rivaroxaban

\section{Key Summary Points}

Protein S deficiency is a predisposing factor for venous thromboembolism, but its role in recurrent arterial ischemic stroke remains uncertain.

Vitamin K antagonists (VKA) have many limitations in recurrent arterial ischemic stroke, and some studies have shown that VKA may transiently suppress the activity of protein $\mathrm{C}$ or $\mathrm{S}$ and exert paradoxical thrombotic effects in thrombophilia.

Direct oral anticoagulants (DOACs) have fewer limitations, and studies have shown that they do not suppress the activity of protein $\mathrm{C}$ or S. However, they are not well studied in recurrent arterial ischemic stroke due to thrombophilia such as protein $S$ deficiency.

In this study, we report that rivaroxaban can be an effective option for secondary prevention of recurrent arterial ischemic stroke due to protein S deficiency. 


\section{DIGITAL FEATURES}

This article is published with digital features, including a summary slide to facilitate understanding of the article. To view digital features for this article go to https://doi.org/10.6084/ m9.figshare.13607024.

\section{INTRODUCTION}

Protein S deficiency is a thrombophilia associated with an increased risk of thromboembolism [1]. Its role as a predisposing factor for venous thromboembolism is well established; however, its role in arterial thrombosis, such as arterial ischemic stroke, remains uncertain [2].

Oral anticoagulant treatment with vitamin $\mathrm{K}$ antagonist (VKA) drugs is used to treat and prevent thromboembolic events caused by thrombophilia. Although VKA drugs are effective in preventing thrombotic events, their efficiency in routine clinical practice is limited. Given these limitations, direct oral anticoagulants (DOACs) are more useful for the treatment and prevention of thromboembolic events $[3,4]$. However, their efficacy in the prevention of thrombosis in patients with protein $S$ deficiency has not been established. In particular, the effect of DOACs on arterial ischemic stroke in patients with a protein $S$ deficiency is not well studied $[5,6]$.

In this article we present a patient with a first diagnosis of protein S deficiency and recurrent ischemic stroke who was treated effectively with rivaroxaban.

\section{CASE PRESENTATION}

A 50-year-old male Iranian patient with a history of recurrent acute neurologic deficit in the past 18 months, including previous stroke 3 months earlier, was admitted to our emergency department in January 2020. Our patient had no symptoms such as migraine headaches, cognitive deterioration, seizure, vision problems, or psychiatric problems. In clinical neurologic examination, he showed acute-onset dysarthria, right-sided hemiparesis and hemihypoesthesia. Other neurologic examinations showed no pathologic findings, and he had no evidence of venous thrombosis. His past medical history indicated a previous hospitalization for ischemic stroke. He had no vascular risk factors (diabetes mellitus, hypertension or smoking). He had been taking aspirin $80 \mathrm{mg} /$ day and rosuvastatin $20 \mathrm{mg} /$ day for the past 2 months.

Brain MRI with diffusion-weighted imaging revealed an acute infarction in the left internal capsule and left corona radiata (Fig. 1). In addition, there was confluent bilateral white matter (T2) hyperintensity in both cerebral hemispheres as well as the pontine area (Fig. 2). There was no evidence of venous thrombosis or micro-bleeding on brain MRI. Brain and cervical MRA did not detect any significant arterial stenosis. Findings of transthoracic echocardiography and duplex ultrasonography were normal. Routine ECG examination showed normal sinus rhythm without abnormal changes. Applying a transesophageal echocardiography (TEE), we found no cardioembolic condition. There were no episodes of atrial fibrillation in 48-h ECG monitoring. There was no minor-risk embolic source identified in our evaluation. His routine blood test, vasculitis screening profile and blood complement levels were normal (Table 1). The patient was monitored in the hospital for 5 days.

Complementary workup investigations for thrombophilia revealed reduced protein $S$ activity (18\%), which was confirmed in a repeated test after 4 weeks. He had not been receiving any medication with possible effects on protein S activity. All his first relatives were tested for protein $S$ deficiency, and none showed positive results. There were also no ischemic or thrombotic complications in his family members.

Because of recurrent ischemic stroke with confirmed protein S deficiency, we started a secondary prophylactic treatment with rivaroxaban $20 \mathrm{mg} /$ day. The patient was followed for the next 12 months at an outpatient clinic. During this period, he was seen every month, and at each visit new neurological symptoms and drug side effects were evaluated. No thrombotic complications or new 

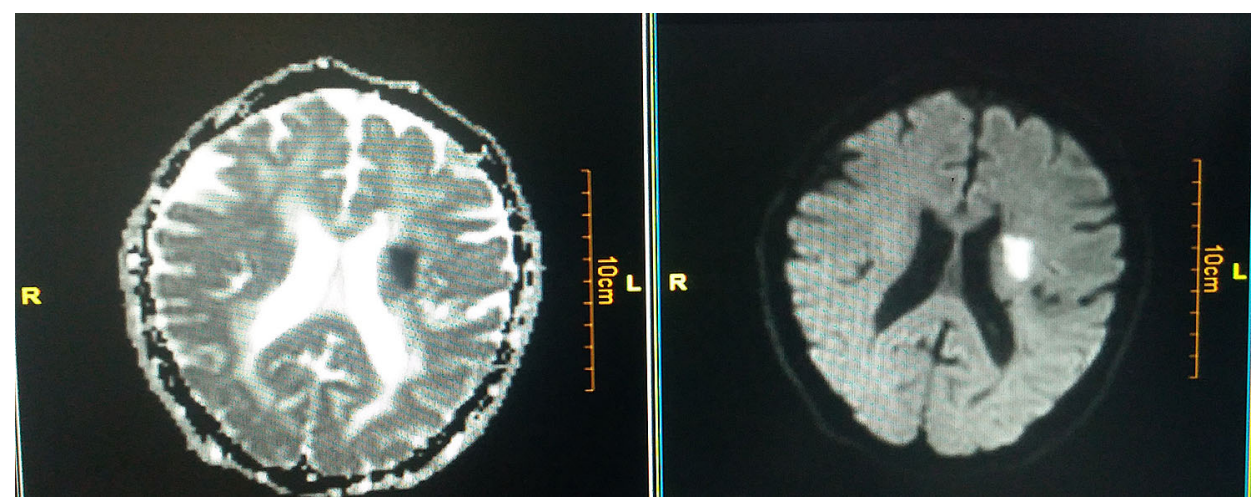

Fig. 1 Brain MRI with diffusion-weighted imaging showed an acute infarction in the left internal capsule and left corona radiata

neurologic deficits occurred. The treatment was well tolerated by our patient, without any complications including hemorrhagic events.

The patients provided informed consent and consent for publication, and the Ethics Committee of the School of Medicine, Isfahan University of Medical Sciences, approved this study. This study was performed in accordance with the Helsinki Declaration of 1964 and its later amendments.

\section{DISCUSSION}

\section{Protein S Deficiency and Recurrent Ischemic Stroke}

Protein S, a cofactor for activated protein C (APC), is a vitamin K-dependent glycoprotein. APC deactivates procoagulant factors $\mathrm{Va}$ and VIIIa and consequently reduces thrombin production and enhances fibrinolysis. This leads to the inhibition of prothrombin activation. Thus, thrombophilia associated with protein $S$ deficiency is a predisposing factor for deep vein thrombosis and pulmonary embolism [7]. Current evidence about its role in arterial thrombosis, such as arterial ischemic stroke, is conflicting. Some case reports have described patients with arterial thrombosis in the setting of protein $S$ deficiency $[1,8,9]$. On the other hand, in a cohort of 3052 healthy men aged 49-64, a reduced free protein $S$ level was not associated with an increased risk of stroke [10].
Similarly, another study of 94 adults admitted for acute cerebral infarction and 94 hospitalized control subjects showed no difference in the prevalence of patients with free protein $S$ deficiency between the two groups [11]. However, in a recent systematic review and meta-analysis by Chiasakul et al., the authors concluded that protein S deficiency was associated with the risk of arterial ischemic stroke in younger adults [12]. The pathophysiologic pathway of arterial ischemic stroke in protein $\mathrm{S}$ deficiency remains unclear [13].

\section{Why We Used Rivaroxaban to Treat This Patient}

There is no specific treatment for patients with protein S deficiency. The use of anticoagulant therapy, however, is suggested for treatment and prevention of thromboembolic events in these patients [12]. In prior studies, VKA (e.g. warfarin) were used to treat and prevent thromboembolic events in patients with a protein $S$ deficiency. Necessary frequent blood tests due to narrow therapeutic index, increased risk of bleeding, various drug and food interactions, and genetic variability in drug metabolism limit the effectiveness in routine administration of these drugs. In this regard, DOACs may be more favorable drugs in clinical practice $[3,4]$. Although controlled studies on administration of DOACs for preventing thrombotic events in patients with protein $S$ deficiency are lacking, observational studies have shown that DOACs 


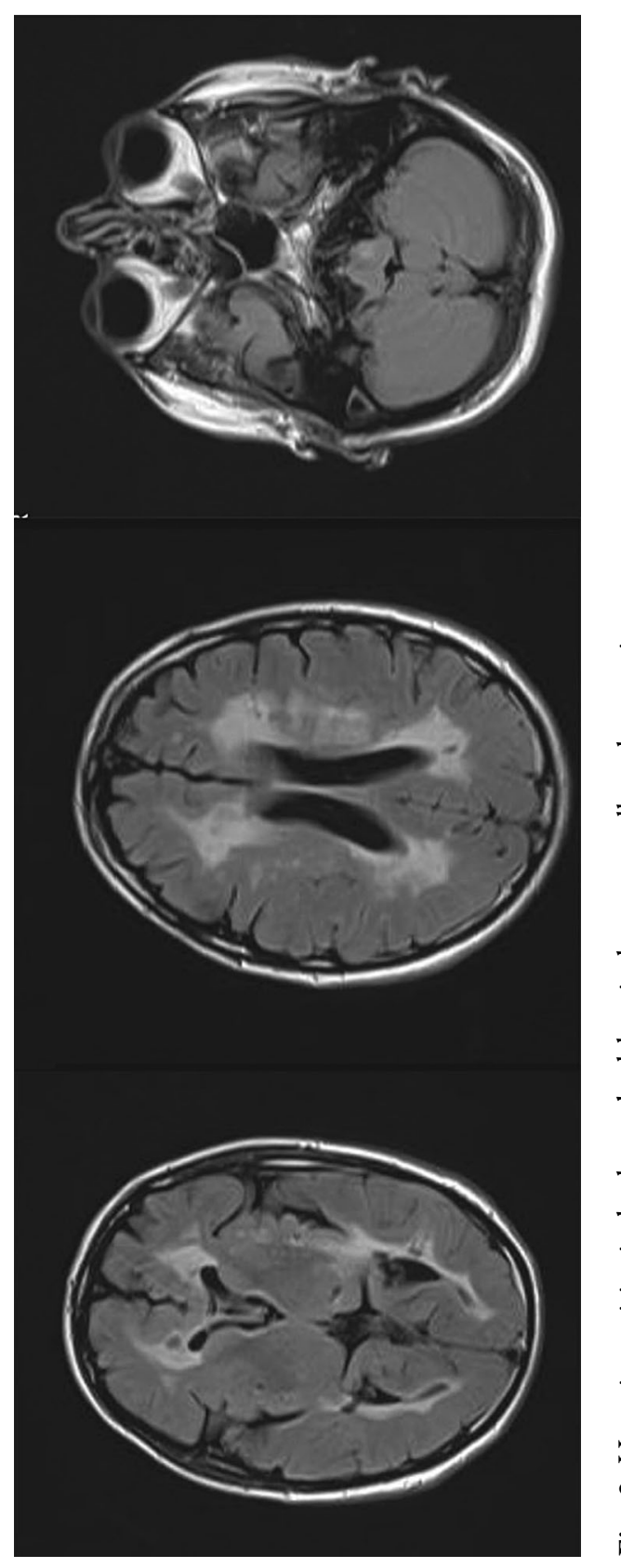

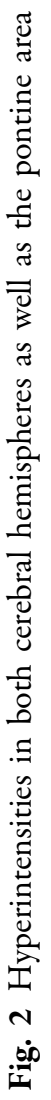

can be administered safely and effectively for treating patients with thrombophilia $[5,6]$.

Some studies have shown that VKA may transiently suppress the activity of protein $\mathrm{C}$ or $\mathrm{S}$, which may promote thrombosis formation in thrombophilia $[14,15]$. Ameku et al. recently reported a patient with protein $\mathrm{S}$ deficiency and recurrent venous thromboembolism (VTE) under treatment with warfarin who was effectively treated with rivaroxaban [15]. A study of 57 patients with acute VTE showed that edoxaban may have more therapeutic benefit than warfarin in VTE patients with or without pulmonary embolism, as it preserves protein $\mathrm{C}$ and protein S levels [16]. Another recently published case report showed that apixaban may be an alternative treatment to VKA for the secondary prevention of ischemic stroke in a patient with protein S deficiency [17]. Several studies have reported on the use of rivaroxaban for secondary prevention in patients with myocardial infarction and recurrent ischemic stroke. Previous studies have concluded that rivaroxaban is safe and effective for secondary prevention in patients with myocardial infarction and recurrent ischemic stroke. Rivaroxaban competitively inhibits factor $\mathrm{Xa}$, and unlike indirect factor Xa inhibitors, rivaroxaban inhibits both free and clot-bound factor $\mathrm{Xa}$, as well as prothrombinase activity, thereby prolonging clotting time [12, 18, 19]. Hence, treatment with DOAC may be more beneficial than VKA in preventing thromboembolic complications of protein $S$ deficiency.

\section{CONCLUSION}

In this report we used rivaroxaban $20 \mathrm{mg}$ /day as secondary prevention for recurrent acute ischemic stroke caused by protein S deficiency. Our patient with a history of recurrent ischemic stroke (three times in the previous 18 months) experienced no acute ischemic stroke or other thromboembolic events during 12 months of follow-up. However, additional controlled studies are needed to evaluate the effectiveness and other aspects of rivaroxaban treatment in recurrent ischemic stroke due to protein $S$ deficiency. 
Table 1 Lab data

\begin{tabular}{|c|c|c|c|c|c|c|c|c|}
\hline & Case & NL & & Case & NL & & Case & NL \\
\hline WBC & 5600 & $4000-10,000$ & Chol & 149 & $<200$ & Antithrombin III & 102 & $72-128$ \\
\hline $\mathrm{RBC}$ & $\begin{array}{c}5.13 \times \\
10^{6}\end{array}$ & $\begin{array}{r}3.9 \times 10^{6} \text { to } 4.9 \times \\
10^{6}\end{array}$ & $\mathrm{TG}$ & 81 & $<200$ & $\begin{array}{l}\text { Beta-2 glycoprotein } 1 \\
\text { antibodies }\end{array}$ & 1.6 & $<15$ \\
\hline $\mathrm{Hb}$ & 15.3 & $12-17$ & $\mathrm{HDL}$ & 41 & $30-70$ & $\begin{array}{l}\text { Antiphospholipid antibodies, } \\
\text { IgG }\end{array}$ & 4.5 & $<12$ \\
\hline Hct & 45.3 & $36-51$ & LDL & 91 & $<150$ & $\begin{array}{l}\text { Antiphospholipid antibodies, } \\
\text { IgM }\end{array}$ & 1.6 & $<12$ \\
\hline Plt & 148,000 & $150,000-450,000$ & pANCA & 1 & $<12$ & $\begin{array}{l}\text { Anticardiolipin antibodies, } \\
\text { IgG }\end{array}$ & 1.5 & $<12$ \\
\hline BUN & 15 & $8-25$ & cANCA & 1 & $<12$ & $\begin{array}{l}\text { Anticardiolipin antibodies, } \\
\text { IgM }\end{array}$ & 2.7 & $<12$ \\
\hline $\mathrm{Cr}$ & 0.9 & $0.5-1.2$ & C3 & 159 & $80-180$ & Lupus anticoagulant & neg & $28-40$ \\
\hline BS & 97 & $<135$ & $\mathrm{C} 4$ & 22 & $10-30$ & Homocysteine & 7.6 & $5-17$ \\
\hline AST & 37 & $<45$ & ANA & 1.6 & $<10$ & Protein $S$ & 18 & $65-160$ \\
\hline ALT & 40 & $<45$ & ESR & 1 & $<10$ & Protein C & 117 & $65-135$ \\
\hline
\end{tabular}

\section{ACKNOWLEDGEMENTS}

Funding. No funding or sponsorship was received for this study or publication of this article.

Authorship. All named authors meet the International Committee of Medical Journal Editors (ICMJE) criteria for authorship for this article, take responsibility for the integrity of the work as a whole, and have given their approval for this version to be published.

Disclosures. Iman Adibi, Saba Naghavi and Ahmad Pourmohammadi declare that they do not have any personal, financial, commercial or academic conflicts of interest.

Compliance with Ethics Guidelines. Informed consent and consent for publication were provided by the patient. The study was approved by the Ethics Committee of the School of Medicine, Isfahan University of Medical Sciences, and was performed in accordance with the Helsinki Declaration of 1964 and its later amendments.

Open Access. This article is licensed under a Creative Commons Attribution-NonCommercial 4.0 International License, which permits any non-commercial use, sharing, adaptation, distribution and reproduction in any medium or format, as long as you give appropriate credit to the original author(s) and the source, provide a link to the Creative Commons licence, and indicate if changes were made. The images or other third party material in this article are included in the article's Creative Commons licence, unless indicated otherwise in a credit line to the material. If material is not included in the article's Creative Commons licence and your intended use is not permitted by statutory regulation or exceeds the 
permitted use, you will need to obtain permission directly from the copyright holder. To view a copy of this licence, visit http:// creativecommons.org/licenses/by-nc/4.0/.

\section{REFERENCES}

1. Wang ZH, Zhao ZJ, Xu K, Sun GB, Song L, Yin HX, et al. Hereditary protein $S$ deficiency leads to ischemic stroke. Mol Med Rep. 2015;12(3):3279-84.

2. Soare AM, Popa C. Deficiencies of proteins C, S and antithrombin and activated protein $\mathrm{C}$ resistancetheir involvement in the occurrence of arterial thromboses. J Med Life. 2010;3(4):412-5.

3. Vinogradova Y, Coupland C, Hill T, Hippisley-Cox J. Risks and benefits of direct oral anticoagulants versus warfarin in a real world setting: cohort study in primary care. BMJ. 2018;362:k2505. https://doi. org/10.1136/bmj.k2505.

4. January CT, Wann LS, Calkins H, Chen LY, Cigarroa JE, Cleveland JC, et al. 2019 AHA/ACC/HRS focused update of the $2014 \mathrm{AHA} / \mathrm{ACC} / \mathrm{HRS}$ guideline for the management of patients with atrial fibrillation: a report of the American College of Cardiology/ American Heart Association Task Force on Clinical Practice Guidelines and the Heart Rhythm Society in collaboration with the Society of Thoracic Surgeons. Circulation. 2019;140(2):e125-51.

5. Skelley JW, White CW, Thomason AR. The use of direct oral anticoagulants in inherited thrombophilia. J Thromb Thrombolysis. 2017;43:24-30.

6. Serrao A, Lucani B, Mansour D, Ferretti A, Baldacci E, Santoro C, et al. Direct oral anticoagulants in patients affected by major congenital thrombophilia. Mediterr J Hematol Infect Dis. 2019;11(1): 2019044. www.mjhid.org. Accessed 22 Sep 2020

7. Seligsohn U, Lubetsky A. Genetic susceptibility to venous thrombosis. N Engl J Med. 2001;344: 1222-31.

8. Usman F, Hassan A, Ahmad A. Arterial ischemic stroke with protein deficiency in Pakistan. Rawal Med J. 2007;32(2):205-9.
9. Hooda A, Khandelwal PD, Saxena P. Protein S deficiency: recurrent ischemic stroke in young. Ann Indian Acad Neurol. 2009;12(3):183-4.

10. Ken-Dror G, Cooper JA, Humphries SE, Drenos F, Ireland HA. Free protein s level as a risk factor for coronary heart disease and stroke in a prospective cohort study of healthy United Kingdom Men. Am J Epidemiol. 2011;174:958-68.

11. Study ACC, Mayer SA, Sacco RL, Hurlet-Jensen A, Shi T, Mohr JP. Free protein s deficiency in acute ischemic stroke. Stroke. 1993;24(2):224-7.

12. Chiasakul T, De Jesus E, Tong J, Chen Y, Crowther M, Garcia D, et al. Inherited thrombophilia and the risk of arterial ischemic stroke: a systematic review and meta-analysis. J Am Heart Assoc. 2019;8(19): e012877.

13. Hviid CVB, Simonsen CZ, Hvas AM. Recurrence risk in patients with cryptogenic stroke, patent foramen ovale, and thrombophilia: a systematic review and meta-analysis. Thromb Haemost. 2019;119(11): 1839-48.

14. Ødegaard OR, Lindahl AK, Try K, Kvalheim G, Sørbø JH. Recurrent venous thrombosis during warfarin treatment related to acquired protein S deficiency. Thromb Res. 1992;66(6):729-34.

15. Ameku K, Higa M. Rivaroxaban treatment for Warfarin-refractory thrombosis in a patient with hereditary protein S deficiency. Case Rep Hematol. 2018;2018:1-5.

16. Yamazaki H, Yagi S, Torii Y, Amano R, Oomichi Y, Sangawa T, et al. Edoxaban improves acute venous thromboembolism while preserving protein $\mathrm{C}$ and protein S levels. J Cardiol. 2018;71(3):305-9.

17. Ohashi I, Wada S, Yoshino F, Kuwashiro T, Matsumoto $S$, Hotta $T$, et al. Ischemic stroke with protein $\mathrm{S}$ deficiency treated by apixaban. J Stroke Cerebrovasc Dis. 2020;29(4):104608. https://doi. org/10.1016/j.jstrokecerebrovasdis.2019.104608.

18. Girgis M, Su Q, Li Q, Jelaidan I. Rivaroxaban for stroke prevention after embolic stroke of undetermined source. N Engl J Med. 2018;379:986-7.

19. Samama MM. The mechanism of action of rivaroxaban-an oral, direct Factor Xa inhibitorcompared with other anticoagulants. Thromb Res. 2011;127(6):497-504. https://doi.org/10.1016/j. thromres.2010.09.008. 